\title{
Case Study of Indoor Air Quality and Energy Efficiency in Passive House in Latvia
}

\author{
Gatis Plavenieks ${ }^{1}$, Arturs Lesinskis ${ }^{2}$, Ilze Dimdina ${ }^{3}$, \\ ${ }^{1,2,3}$ Riga Technical University
}

\begin{abstract}
This paper presents a case study of a residential passive house in Latvia. Indoor air quality was measured during autumn and winter. The main objective of the study is to determine indoor air quality parameters in the new passive house building- air temperature, relative humidity and $\mathrm{CO}_{2}$ level. This paper will be illustrated with pictures, tables, and construction elements of the passive house.
\end{abstract}

Keywords - indoor air quality, passive houses, air handling units, energy efficiency.

\section{INTRODUCTION}

The European Union's energy consumption is growing each year, along with its dependence on external oil and gas suppliers. The Union's buildings consume $40 \%$ of the total energy consumption in Europe [1]. Currently, the most suitable in terms of energy efficiency are passive, net zero energy, low energy consumption, 30 litre houses [2]. The passive house standard originated May 1988. The international definition has been developed by the Passive House Institute. As of August 2010, there were approximately 25000 such certified structures of all types in Europe [3]. At the present in Latvia- there are several public buildings and private houses. The Latvian passive house standard has been developed neither for public, nor for residential buildings and has not adopted. The single family house "Daugavinas" is one of the first in Latvia to be built up according passive house standard, U-values - see Table I.

The objective of the work is to find out the indoor air parameters of the passive house.

\section{METHODS}

The house was put in operation in 2011. The house is located $40 \mathrm{~km}$ from the capital of Latvia, next to the River Daugava (Fig.1). Total building area is $158 \mathrm{~m}^{2}$, but only $98 \mathrm{~m}^{2}$ require heating.

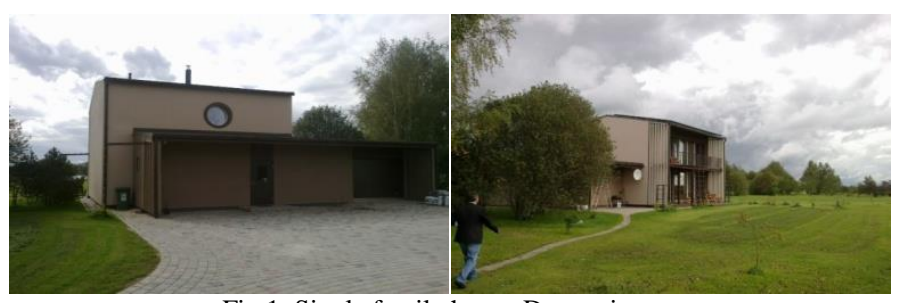

Fig.1. Single family house Daugavinas.
On the first floor, there is an open space with a living room and a kitchen, but on the second floor there is a bedroom, cabinet, technical room and bathroom. The south side of the building has glass windows in both floors. On the west and east side of the building, there is only a wall (no windows, no doors). On the north side, the main entrance door and a round window on the second floor are located (Fig.2). The building was designed for 2 persons.

TABLE I

SINGLE FAMILY HOUSE DAUGAVINAS DESIGN INFORMATION

\begin{tabular}{|c|c|c|c|}
\hline Item & Materials & Area, $\mathrm{m}^{2}$ & $\begin{array}{l}\mathrm{U} \text { value, } \\
\mathrm{W} /\left(\mathrm{m}^{2} \mathrm{~K}\right)\end{array}$ \\
\hline $\begin{array}{l}\text { Floor on } \\
\text { the soil }\end{array}$ & $\begin{array}{l}\text { Reinforced concrete } \\
\text { with XPS }\end{array}$ & 76.28 & 0.105 \\
\hline Wall & $\begin{array}{l}\text { Double wood frame } \\
\text { with insulation }\end{array}$ & 152 & 0.077 \\
\hline Roof & $\begin{array}{l}\text { Double wood frame } \\
\text { with insulation }\end{array}$ & 78.2 & 0.074 \\
\hline Windows & Triple glass & 40 & 0.739 \\
\hline Door & $\begin{array}{l}\text { Wood with glass } \\
\text { window }\end{array}$ & 2.1 & 0.8 \\
\hline
\end{tabular}

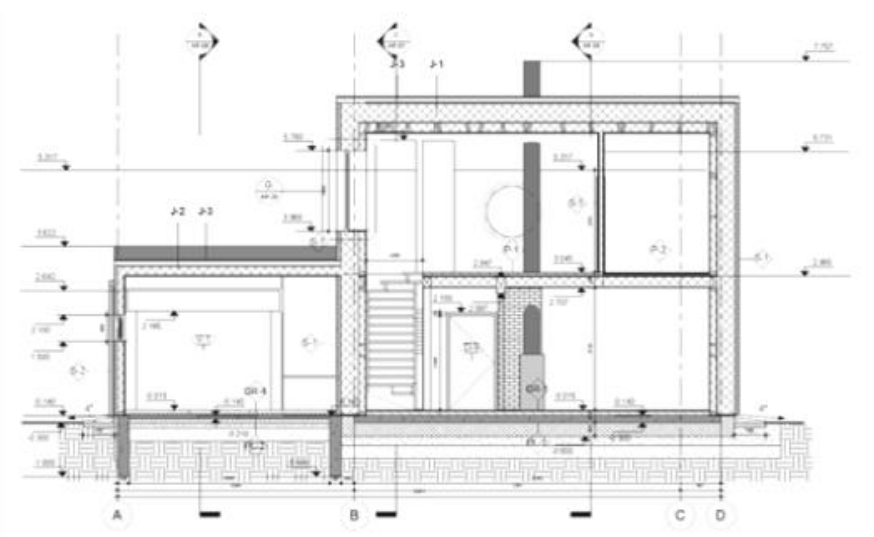

Fig.2. Vertical section of single family house 'Daugavinas'.

Building volume is $268 \mathrm{~m}^{3}$. Supply and exhaust mechanical ventilation system with air flow $130 \mathrm{~m}^{3} / \mathrm{h}$ which provide $0.5 \mathrm{~h}^{-1}$ air exchange per hour designed for the building. According to air handling unit producer presented the certificate, heat recovery has to be $\eta=90.6 \%$. The average air exchange round of building is $0.32 \mathrm{~h}^{-1}$ (ventilation) and $0.041 \mathrm{~h}^{-1}$ (infiltration). According to temporary energy efficiency certificate for a 
single family house, total energy consumption was 4.1 $\mathrm{MWh} / \mathrm{y}$ :

- heating 1.7 MWh/y;

- hot water $0.7 \mathrm{MWh} / \mathrm{y}$;

- light $0.2 \mathrm{MWh} / \mathrm{y}$;

- ventilation $1.5 \mathrm{MWh} / \mathrm{y}[4,5,6]$.

The blow door test was done after the construction process was completed. Building air tightness at $50 \mathrm{~Pa}$ pressure (according to the performed measurements) is $0.09 \mathrm{~h}^{-1}$ [4].

The indoor air quality at the residential building "Daugavinas" was evaluated during autumn and winter time. Temperature and relative humidity as thermal comfort indicators were measured in the indoor environment. Carbon dioxide $\left(\mathrm{CO}_{2}\right)$ was used like indoor air quality indicator, where human is main source of pollution with set-up till 700 ppm (expressed in parts per million) is seen like good and from 700 to $1000 \mathrm{ppm}$ as normal conditions. The measurement data were used by the data logger Wohler CDL 210:

- Temperature tolerance $+/-0.6{ }^{\circ} \mathrm{C}$ between $-10^{\circ} \mathrm{C}$ to +60 ${ }^{\circ} \mathrm{C}$;

- Relative humidity tolerance $+/-3 \%$ between 10 to $90 \%$;

- Carbon dioxide $\left(\mathrm{CO}_{2}\right)$ tolerance +/- $50 \mathrm{ppm}+/-5 \%$ between 0 - 20000 ppm.

The measurements in the house were made for 1 week in autumn from October 17 to 24, 2012, and for 3 weeks in winter period from February 18 to March 14, 2013. All measurements were performed during 24 hours per day with 5 minutes interval. During the period of indoor air quality parameters measurement, owner was asked not to open the windows. The rule was kept. During this period, 2 persons were living in the house and several more persons stayed in the house temporarily. The mechanical ventilation was used 24 hours per day.

The information of the outside temperature during the first measurement period is presented in Fig.3 [7]. The indoor air quality measurement data are presented in Fig.4. Outside temperature was between $6^{\circ} \mathrm{C}$ to $12^{\circ} \mathrm{C}$ during this period. In the same period carbon dioxide concentration was between $417 \mathrm{ppm}$ to $914 \mathrm{ppm}$.

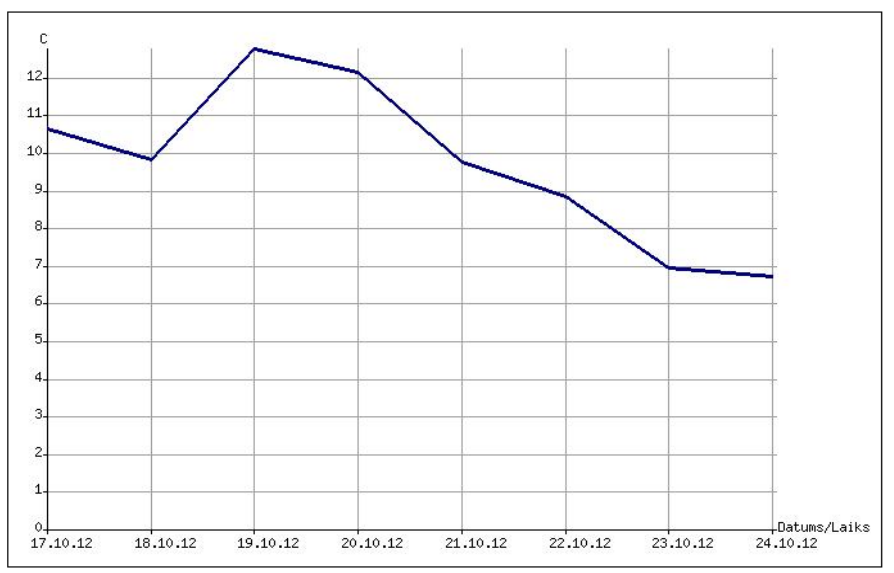

Fig.3. Average outside temperature from 17 October to 24 October 2012.

TABLE II

STATISTICS OF TEMPERATURE, RELATIVE HUMIDITY AND $\mathrm{CO}_{2}$ MEASUREMENTS FROM 17 OCTOBER TO 24 OCTOBER 2012.

\begin{tabular}{|l|l|}
\hline Parameter & Value \\
\hline Average $\mathrm{CO}_{2}$ level, ppm & 617 \\
\hline $\mathrm{Max} \mathrm{CO}_{2}$ level, ppm & 914 \\
\hline Min $\mathrm{CO}_{2}$ level, ppm & 455 \\
\hline Average temperature, ${ }^{\circ} \mathrm{C}$ & 20 \\
\hline Max temperature, ${ }^{\circ} \mathrm{C}$ & 24.3 \\
\hline Min temperature, ${ }^{\circ} \mathrm{C}$ & 18 \\
\hline Average RH level, $\%$ & 47 \\
\hline Max RH level, $\%$ & 65 \\
\hline Min RH level, \% & 41 \\
\hline
\end{tabular}

Statistical temperature, relative humidity and carbon dioxide values are summarized in Table II. Minimal and maximal values per measurement period, as well as average parameters values are shown.

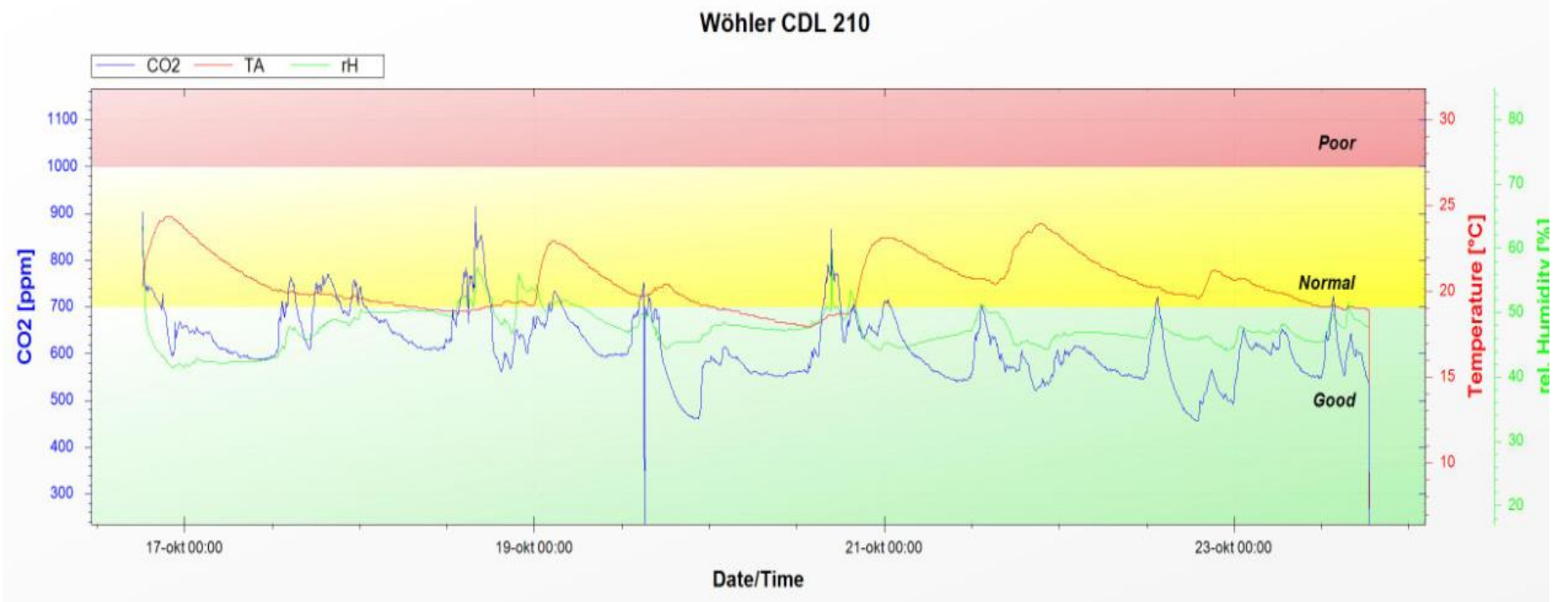

Fig.4. Temperature, relative humidity and $\mathrm{CO}_{2}$ measurements from 17 October to 24 October 2012. 
The second measurement period lasted for 3 weeks during winter period from 18 February to 14 March 2013. During this period, 2 persons were living in the house. The mechanical ventilation was operated 24 hours per day.

\section{TABLE III}

MEASURED DATES STATISTICS OF TEMPERATURE, RELATIVE HUMIDITY AND $\mathrm{CO}_{2}$ MEASUREMENTS FROM 18 FEBRUARY TO 14 MARCH 2013.

\begin{tabular}{|l|l|}
\hline Parameter & Value \\
\hline Average $\mathrm{CO}_{2}$ level, ppm & 596 \\
\hline Max $\mathrm{CO}_{2}$ level, ppm & 947 \\
\hline Min $\mathrm{CO}_{2}$ level, ppm & 359 \\
\hline Average temperature, ${ }^{\circ} \mathrm{C}$ & 21 \\
\hline Max temperature, ${ }^{\circ} \mathrm{C}$ & 27.6 \\
\hline Min temperature, ${ }^{\circ} \mathrm{C}$ & 16.5 \\
\hline Average RH level, \% & 40.8 \\
\hline Max RH level, $\%$ & 56.7 \\
\hline Min RH level, \% & 29.9 \\
\hline
\end{tabular}

The information of outside temperature during the second measurement period is presented in Fig.5 [7]. The indoor air quality measurement data are presented in Fig.6. Outside temperature was between $-9{ }^{\circ} \mathrm{C}$ to $+3{ }^{\circ} \mathrm{C}$ during this period. In the same period carbon dioxide concentration was between $359 \mathrm{ppm}$ to $947 \mathrm{ppm}$.

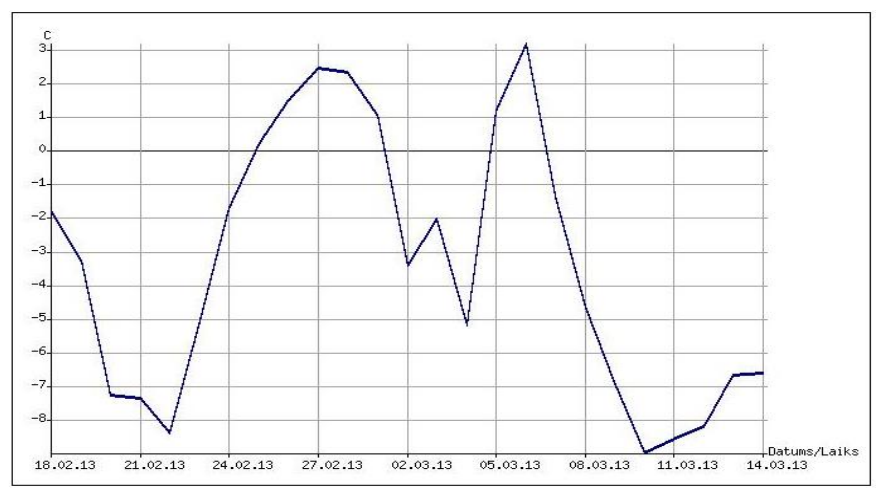

Fig.5. Average outside temperature from 18 February to 14 March 2013.

\section{DISCUSSION}

The definition of a high energy efficiency house parameters and designation differs in various countries and depends on the local climatic conditions and building codes. The single family house Daugavinas was planned and designed according to passive house criteria, before 2011. According to PHPP calculations presented by the owner energy consumption was $17 \mathrm{kWh} / \mathrm{m}^{2}$ per year $[4,5]$, but passive house standard requires it to be for $15 \mathrm{kWh} / \mathrm{m}^{2}$ per year [3]. At the same time pressurization test and specific primary energy demand meet passive house standard. Heat consumption was monitored during 2011 heating season and heat demand was $16.72 \mathrm{kWh} / \mathrm{m}^{2}$ per year. The requirement for nearly zero energy houses was defined in the legislations norms for building energy classification in Latvia only from 2013 [8]. Like energy efficiency class "A" for nearly zero energy houses the requirements are defined as the heat demand up to $30 \mathrm{kWh} / \mathrm{m}^{2}$ per year, ventilation system with minimum 75\% heat recovery and other criteria, in 2013. Single family house "Daugavinas" fulfill "A" class requirements on the heat demand and heat recovery efficiency. To achieve this heat demand level for " $A$ " class buildings, higher requirements for new and renovated building thermal envelope entered into force only at 2014 [9]. Requirements of legislations norms in Latvia from 2003 to 2014 for new and renovated building thermal envelope provided heat demand $100 \mathrm{kWh} / \mathrm{m}^{2}$ per year in average. In this period different energy efficiency assessment scales of buildings was discussed, oriented to the enough high energy efficient buildings with heat demand about 60 to $100 \mathrm{kWh} / \mathrm{m}^{2}$ per year $[10,11]$.

According to the measurements of temperature and relative humidity and carbon dioxide, the ventilation system provided good indoor air quality. The mechanical ventilation was used 24 hours per day without opening of windows during all measurement period. It was found out that most of time in autumn, temperature and relative humidity were kept in the thermal comfort range.

Lower indoor temperature under $+18^{\circ} \mathrm{C}$, but not less $+17^{\circ} \mathrm{C}$,

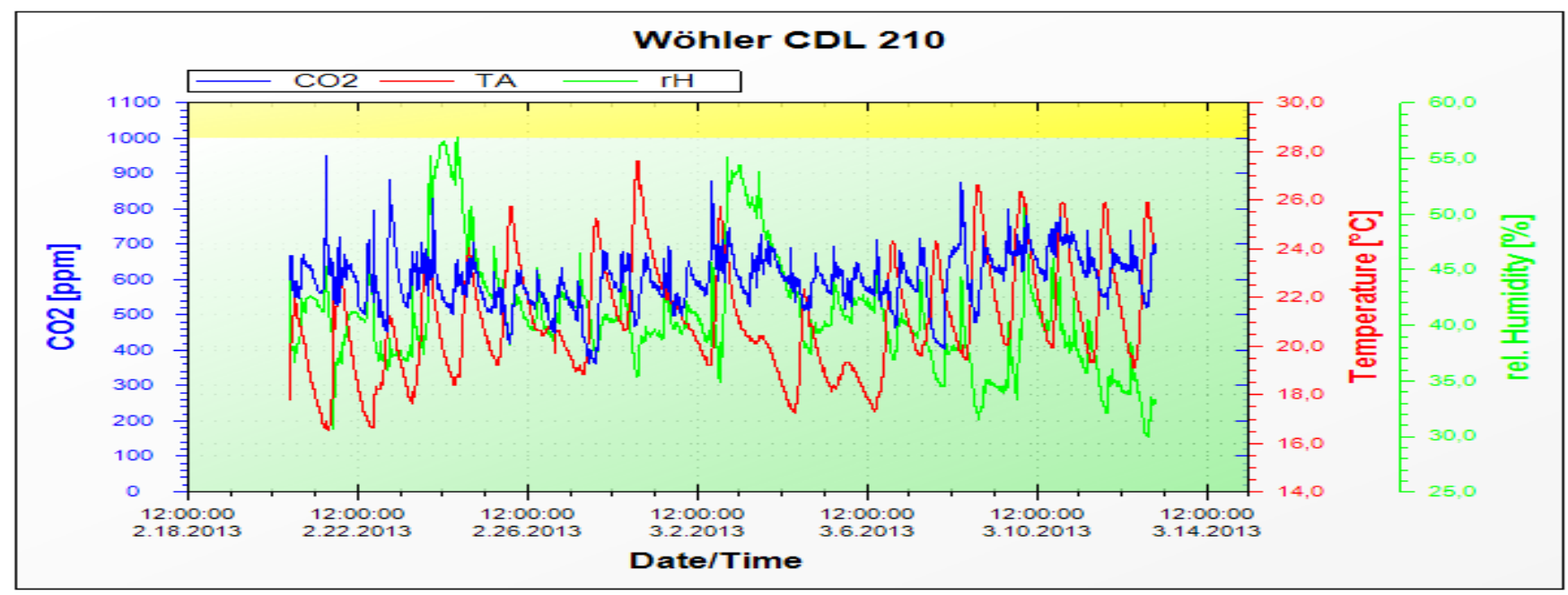

Fig.6. Temperature, relative humidity and $\mathrm{CO}_{2}$ measurements from 18 February to 14 March 2013. 
was fixed some days during the night time when the outside temperature was less than $-7{ }^{\circ} \mathrm{C}$. Higher indoor temperature above $+25{ }^{\circ} \mathrm{C}$ were fixed on some days during the day time when the sun was shining.

In the same period carbon dioxide concentration was between $359 \mathrm{ppm}$ to $947 \mathrm{ppm}$. Throughout most of measurement period, for $85 \%$ of the time carbon dioxide concentration was at a good level and for only $15 \%$ of time at the normal level. The highest level of carbon dioxide concentration was connected to low outside temperatures and residents spent more time inside the house. Throughout most of the measurement period, for $87 \%$ of the time, carbon dioxide concentration was at good level and only for $13 \%$ of time at the normal level.

Comparing studies of the natural ventilation effects on the indoor air quality [12] certifies that maintain a constant $\mathrm{CO}_{2}$ concentration level up to 1000ppm for all living and sleeping spaces is not possible without additional operational rules, for example, to hold open the bedroom door at nighttime. Natural ventilation in the cold climate conditions, also affect the indoor air temperature fluctuations in largest range and local discomfort risks due to the supply air temperature and supply unit placement in the room. The mechanical ventilation is clearly superior in comparison with natural ventilation in residential homes ensuring a high level of indoor air quality and a significant reduction of the heating energy consumption $[12,13]$. The analyses of life cycle assessment (LCA) and life cycle costs (LCC) for residential ventilation units with heat recovery in a cold climate shows that the start investments are significantly lower than the long-term energy savings for heating. Primary energy consumption depending on the origin of energy for heating and fan operation may not otherwise change significantly [14]. Heating consumption potential savings necessarily depend on the efficiency of heat recovery unit and the potential to reduce the consumption of energy required for heating the air before or after the heat exchanger to prevent the heat exchanger from freezing risks and discomfort due to lower supply air temperature [12, 13, 14, $15]$.

The single house "Daugavinas" has fire place as heating system. Ashen wood used during heating of the house. Fireplace firing frequency and outdoor temperature fluctuation range of day period directly affects to the fixed indoor temperature variation in the measurement period.

Relative humidity curve is directly dependent on the room temperature and followed by fluctuations. The average relative humidity indoors decreases, when the outdoor air temperature is decreasing, because of the reduced absolute moisture content of ventilation supply air. Cold climate conditions in rooms with adequate ventilation to ensure $\mathrm{CO}_{2}$ levels up to $1000 \mathrm{ppm}$, characterized by the relative humidity indoors, on average, less than $30 \%$ [16].

\section{CONCLUSIONS}

This case study evaluated thermal comfort and indoor air quality of the new building. Thermal comfort parameters, such as temperature and relative humidity, were measured. Concentration of carbon dioxide used as an indoor air quality parameter was measured as well. All three parameters were measured in the same time periods - for 1 week autumn and for 3 weeks in the winter period. According to these measurements, single family house "Daugavinas" has a good indoor climate. Deviation of maximal and minimal values of each parameter was within good indoor quality range, except some values. The measurements showed direct influence of outdoor air temperature and sun on the indoor air quality parameter- temperature- in this case study. Temperature fluctuations are also significantly influenced by the selected type of heating and residents habits of heating operation.

The possibility to ensure the space relative humidity in the comfort range depends on the outdoor air temperature and desired $\mathrm{CO}_{2}$ concentration level in cold climate conditions. Depending on the individual sensitivity of the residents to these air parameters, it is possible to reduce the room temperature and the amount of supply air, to ensure the optimal combination of the all indoor air quality parameters temperature, relative humidity and $\mathrm{CO}_{2}$ concentration level.

Single family house "Daugavinas", was planned and designed according to passive house criteria before local legislations requirements of nearly zero energy houses entered into force. Achieved energy performance of the building 16.72 $\mathrm{kWh} / \mathrm{m}^{2}$ per year heat consumption does not fulfill the requirements of the passive house criteria, but are very close. At the same time, it is almost 2 times above local requirements for "A" class nearly zero energy house criteria. Without mechanical ventilation with high efficiency heat recovery, such a good heat consumption result and indoor air quality would not be achievable.

\section{ACKNOWLEDGEMENT}

We thank the owner of the single family house Mr. Voldemars Janis Upleja for hospitality and permission to take measurements, as well as for supporting the work and materials provided.

\section{REFERENCES}

[1] Eiropas Parlamenta un Padomes Direktīva, 2012/27/ES (2012. gada 25. oktobris) par energoefektivitāti, ar ko groza Direktīvas 2009/125/EK un 2010/30/ES un atcel Direktīvas 2004/8/EK un 2006/32/EK [Online] Available: http://eur-ex.europa.eu PDF [Accessed: Feb. 09, 2013].

[2] V. A. Sterling, A handbook of sustainable building design and engineering: an integrated approach to energy, health and operational performance, London: Earthscan, 2009, pp. 435.

[3] Passivhaus Institut. Available at: http://www.passiv.de, [Online] [Accessed 24 November 2014].

[4] E. Krauklis '’Daugaviṇas,', Latvijas Architektūra, pp.24-28, 2012. [Online]. Available: http://bis.gov.lv [Accessed 04 September 2014].

[5] Ēkas Energoefektivitātes Pagaidu Sertifikāts from 2011.12.15.

[6] http://labsnams.lv/lv/projects/passive-house/pasivas-majas-projektslatvija/ [Online] [Accessed: Dec. 12, 2014].

[7] Gaisa temperatūra [Online] Available: www.rs.lv [Accessed: Mar. 30, 2013].

[8] Ministru kabineta noteikumi Nr. 383 no 09.07.2013., Noteikumi par ēku energosertifikāciju.

[9] Ministru kabineta noteikumi Nr. 495 no 27.11.2001., Noteikumi par Latvijas Būvnormatīvu LBN 002-01 „Ēku norobežojošo konstrukciju siltumtehnika".

[10] A. borodinecs, E. Dzelzitis, A. Kreslins, General requirements for the energy performance of buildings in Latvia// Proc. 9th REHVA World Congress "WellBeing Indoors - Clima 2007", June 10-14, 2007, Helsinki, Finland, pp. 7. 
[11] Dz.Grasmanis, A.Malnieks, A.Jekabsons, Implementation of the EPBD in Latvia , Brussels: European Union, 2011, p.III-223-234.

[12] C. Simonson, Energy consumption and ventilation performance of a naturally ventilated ecological house in a cold climate, "Energy and Buildings", Volume 37, pp 23-35, 2005. http://dx.doi.org/10.1016/j.enbuild.2004.04.006

[13] Mechanical ventilation with heat recovery in cold climates [Online] Available: http://web.byv.kth.se/bphys/reykjavik/pdf/art_157.pdf [Referred on the 2th of January in 2013].

[14] M. Nyman, C.J. Simonson, Life cycle assessment of residential ventilation units in a cold climate, "Building and Environment", Volume 40, pp 15-27, 2005. http://dx.doi.org/10.1016/j.buildenv.2004.04.011

[15] G. Plavenieks, A. Lesinskis, Case study of energy efficiency in air handling units with heat exchangers for residential application in Latvia// Proc. 4th International Conference "Civil Engineering'13", May 16-17, 2013, Jelgava, Latvia, pp. 240-244.

[16] I. Dimdina, E. Krumins, A.Lesinskis, Indoor air quality in multiapartment buildings before and after renovation, "Constructions Science", Volume 16, pp. 4-10, 2014. 